\title{
SOME RELATIONS OF ORGANIC MATTER IN SOILS
}

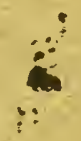

\section{A THESIS}

PRESENTED TO THE FACULTY OF THE GRADUATE SCHOOL OF CORNELL. UNIVERSITY FOR THE DEGREE OF

\section{DOCTOR OF PHILOSOPHY}

BY

\section{FRED ALBERT CARLSON}

FEBRUARY, 1922

Reprinted from Memoir 61, September 1922, Cornell University Agriculture Experiment Station. 


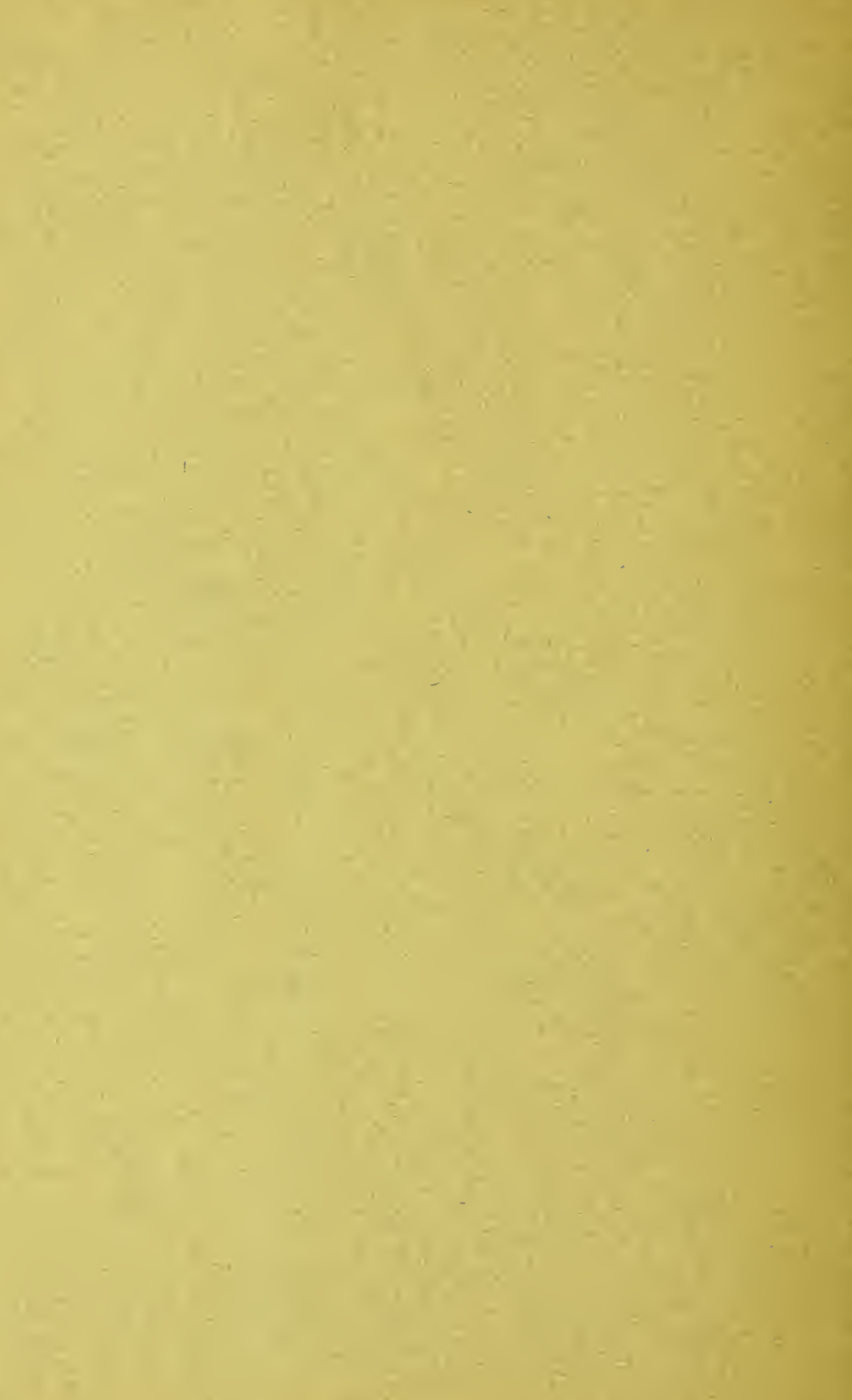




\title{
SOME RELATIONS OF ORGANIC MATTER IN SOILS
}

\author{
A THESIS \\ PRESENTED TO THE FACULTY OF THE GRADUATE SCHOOL \\ OF CORNELL UNIVERSITY FOR THE DEGREE OF \\ DOCTOR OF PHILOSOPHY
}

BY

FRED ALBERT CARLSON

FEBRUARY, 1922

Reprinted from Memoir 6r, September 1922, Cornell University Agriculture Experiment Station. 


$$
\begin{aligned}
& 55^{9,3} \\
& C^{35}
\end{aligned}
$$




\section{SOME RELATIONS OF ORGANIC MATTER IN SOILS}

\section{F. A. Carlsox}

The effect of lime on the organic matter in soils has been for some time one of the leading problems for investigation. The results that have been recorded, however, are not consistent. Some investigators have reported that there is a greater accumulation of organic matter in limed than in unlimed soil, while others have stated the contrary. This difterence of opinion is not surprising when the methods of experimentation, the soil variations, and the climatic conditions are considered. There has been, however, too great a tendency to draw conclusions from unreliable data. In many cases. attempts have been made to study the effect of lime on the organic matter in soils without a knowledge of the composition of the soils before treatment.

In view of the many discrepancies in the reported results. the present experiment was designed to ascertain the effect of lime on the organic matter in soils under varions treatments and cropping systems.

\section{HISTORICAL}

Wheeler and others $(1899)^{1}$ reported that lime decreased the percentage of humus in soils under continuous culture of cereals. They found also that there was an increase of roots and residual organic matter in limed giass plats as compared to those not limed.

Hess (1901) studied the elfect of lime on some of the Pennsylvania soils. He stated that liming resulted in a diminution of the nitrogen.

Kossovich and Tretjakov (190\%) stated that the addition of calcium carbonate to soil retarded the decomposition of organic matter.

Hartwell and Kellogg (1906) pointed ont that the amount of humus in limed plats was less than that in mlimed plats. They stated also that the effect produced by lime upon the organic matter of a given soil was dependable to a considerable extent on the degree of acidity or of alkalinity of the soil.

${ }^{1}$ Dates in parenthesis refer to References Cited, page. 25. 
Pot experiments by Clausen (1906) conducted with clover and oats on sandy soil indicated that applications of lime resulted in a marked nitrogen hunger, especially during dry, hot weather and with non-leguminous crops.

Van Suchtelen (1910) found in laboratory experiments that soils treated with calcium oxide produced less carbon dioxide than did unlimed soils.

Alway and Trumbull (1910) say:

In a comparison of 22 rotation plots 110 distinct relation has been found between the composition of the soil and the nature of the rotation. In a long cultivated field the till was found poorer in humus, nitrogen and organic carbon than the lacustral clay. The amounts of the above three constituents found in any of the plots depend more upon the relative proportions of the two types of soil occurring on the plots than upon the previous treatment.

The longer the fields have been kept in grasses mown for hay, the less has been the change in composition of the soil. Continuous bare cultivation along tree rows has caused greater losses than the alternation of fallow and crop in the adjacent fields. The extreme loss of nitrogen, humus and organic carbon in 25 years is about one-third of the amounts originally present in the prairie.

Bradley (1912) conducted pot experiments from which he pointed ont that the nitrogen loss was appreciably reduced by legnines.

Mooers, Hampton, and Huntel (1912) reported that the loss of nitrogen was appreciably greater on limed plats than on unlimed plats, and that the effect extended below the depth of plowing. These investigators stated also that there was an increase in percentage of humus on the unlimed sections.

McIntire (1913) writes:

Burnt lime decreased the organic matter when applied alone and lessented the accumulation when applied with manure.

Calcium sulphate and gromnd limestone increased organic natter.

Each form of lime resulted in an increase of nitrogen content, gypsum. limestone, and burnt lime, being effective in the order named.

Lipman and Blair (1913) reported that in their experiments the limed plats had lost nitrogen to a greater extent than had the unlimed plats.

Gardner (1914) says: "Burnt lime appears to exhaust the humus in the soil more rapidly than ground limestone. Burnt line with manure gave returns over manure alone. . . . It is desirable that the use of lime or limestone lead to larger supplies of organic matter in the soil."

Swanson (1915) reported results based on the chemical analyses of cultivated and uncultivated soils in seven representative counties in Kansas. He pointed out that the elements 
carbon and nitrogen have disappeared from the cultivated soils to a larger extent than from the uncultivated soils. He showed that the cultivated soils had lost, in round numbers, from onefifth to two-fifths of the nitrogen and from one-fourth to onehalf of the organic matter.

Potter and Snyder (1916) stated that in a general way the total nitrogen determinations in their experiments showed that there was a smaller loss or a greater gain of nitrogen for the limed soils than for the corresponding unlimed soils.

Bear (1916) indicated that quicklime reduced the amount of carbon and of nitrogen in the soil.

Potter and Snyder, in a later experiment (1917), concluded that lime in the form of a carbonate, under the conditions of the experiment, appreciably enluanced the rate of decomposition of both original soil organic matter and the organic matter of stable manures, oats, and clover when added to the soil. They stated that two of the more important results of this were the increased availability of plant food and the more rapid depletion of the soil organic matter. They pointed out that the latter effect would be partially and perhaps entirely offset by the fact that with lime larger crops could be grown, which would add more organic matter as crop residue to the soil.

Breazeale (1917) found that calcium carbonate had a slight destructive action upon the organic matter of the soil.

Jensen (1918) stated that in most cases when lime was added to alfalfa in basins, greater increase in the humus content occurred than when alfalfa alone was used.

Christie and Martin (1918) state that it is evident from data considered that all soils do not react chemically with lime in the same manner.

Bizzell and Lyon (1918) write: "On Volusia silt loam addition of quicklime increased the amount of carbon dioxide in the soil air. This effect was noticed both on the cropped and uncropped tanks. On Dunkirk clay loam quicklime apparently produced no effect."

Swanson and Latshaw (1919) say:

In the sub-humid section the fields cropped to grain lost one-fourth of the nitrogen as compared with the surface soil of the native sod. The alfalfa fields contain 5 per cent less nitrogen than the native sod, but 20 per cent more than the fields in grain.....

In the semi-arid section the cropped soil has lost one-fifth of the nitrogen as compared with the native sod. Alfalfa fields contained 15.7 per cent 
more nitrogen than the soils in native sod, and 30 per cent more than the solis continuously cropped.

In the lumid section, the cropped soils have lost 36 per cent of the organic carbon present in the ringin sod and those in alfalfa over 21 per cent.

Lipnan and Blair (14:0 a) smmmarized a series of experiments as follows:

Lime in the carbonate form wa- used on a loam soil at the rate of 1 ton per acre for the first 5 rears and 2 tons for the second 5 years in a 5-year rotation of corm, oats, wheat and 2 years of timothy. No legume crops were introduced. Twenty plots with different nitrogen treatment were thus limed and twenty similar plots with parallel nitrogen treatment were left without lime.

The total yields of dry matter and of nitrogen for the 10 -year period were essentially the same for the two sections.

Analyses of the soil made soon after the work was started and again at the end of each 5-year period showed that there was a loss of nitrogen from both the limed and unlimed sections. However, the loss from the limed section was distinctly greater than from the unlimed section.

Thus at the end of the 10-year period, there was a positive loss rather than gain from the use of lime.

From this work it would appear that the practice of using lime on light to medium heavy soils. when leguminous crops are not grown in the rotation, may be questionable. Under such conditions it is quite possible that a slightly acid reaction may be desirable to prevent the too rapid oxidation of organic matter.

The second five-years period showed a distinct loss in carbon from both series, but a greater loss from the limed than from the unlimed plats.

Lipman and Blair (1920 b) reported also a series of experiments which included rotations with legumes. They pointed out that during the ten vears. the limed plots, with only slight exceptions, yielded distinctly larger crops and more total nitrogen than did the unlimed plots. In analyzing the soil they found that in a number of cases the limed plots contained more nitrogen than did the unlimed plots.

The same investigators (Lipman and Blair, 1921) reported the results of expeliments in studying the losses of nitrogen and organic carbon from a loam soil (in cylinders with natural (lrainage) which for twenty years had been under a five-years rotation of corn, oats (two years). wheat, and timothy. They found that in most cases there was a general decline in the nitrogen and the organic carbon content. They pointed out that there was a lower nitrogen and organic carbon content in the limed soils than in the unlimed soils. They stated also that the legume green-manure crops tended to raise the nitrogen content.

It is quite impossible to make any direct comparison of 
the literature cited, due to the variations in experimental methods and in representation of results. In fact. in many cases there are $n$ o data to substantiate the statements made. Furthemore. the making of comparisons of one plot with another on the assumption that the natural variation in fertility is gradual and uniform, is subject to severe criticism. It is likewise impossible to study the effect of lime on organic matter in soils without knowing the original composition of the soils. Also, conclusions drawn from computations based on analyses of soils taken adjacent to plats under treatment and assuming that the results obtained represent the original analyses of the treated plats, are questionable. However, the general conception expressed by the literature is that plats which have been limed contain less organic carbon and less nitrogen than do those which have not been limed. There are some exceptions. This conclusion is based on very limited experimental data.

\section{EXPERIMENTAL}

In the present investigation two series of field plats, each 1-100 acre in size, were used. The plats were sampled both before and after treatment. The soil was analyzed for inorganic carbon, organic carbon, and nitrogen.

The soil on these plats consists of glacial material reworked by streams and redeposited from glacial lakes (Lyon and Bizzell. 1918). Owing to its sedimentary origin it is comparatively free from stones. The soil has been classified by the Lnited States Soil Survey as Dunkirk clay loam. It is a heavy, compact soil, and requires careful management. Its average mechanical analysis is as follows:

\begin{tabular}{|c|c|c|}
\hline & $\begin{array}{l}\text { First } \\
\text { foot } \\
\text { (per cent) }\end{array}$ & $\begin{array}{c}\text { Second } \\
\text { toot } \\
\text { (pel cent) }\end{array}$ \\
\hline Fine gravel & $\ldots 0.40 \ldots$ & $\ldots 0.13$ \\
\hline Coarse sand ... & $\ldots 11.63 \ldots$ & $\ldots 0.37$ \\
\hline Medium sand. & $\ldots 11.53 \ldots$ & $\ldots 0.52$ \\
\hline Fine sand ..... & $\ldots 1.55 \ldots$ & $\ldots 1.65$ \\
\hline Tery fine sand & $\ldots 12.90 \ldots$ & $\ldots 11.27$ \\
\hline Silt $\quad \ldots \ldots \ldots$ & $\ldots 601.53 \ldots$ & $\ldots .53 .95$ \\
\hline Clay & . 22.6.3. . . & $\ldots .32 .72$ \\
\hline
\end{tabular}




\section{A. ( ARLSON}

The following chemical composition was determined by Lyon and Bizzell from representative samples:

('onstituents determined $\begin{array}{cc}\text { First } & \text { Second } \\ \text { toot } & \text { foot } \\ \text { (per cent) cent) }\end{array}$

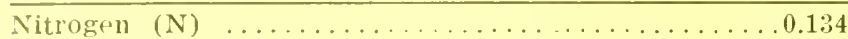

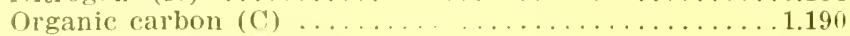

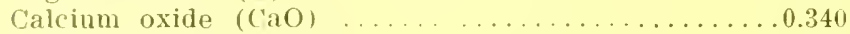

Magnesium oxide $(\mathrm{MgO}) \ldots \ldots \ldots \ldots \ldots \ldots \ldots \ldots \ldots . \ldots \ldots . \ldots \ldots$

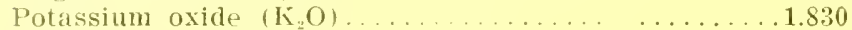

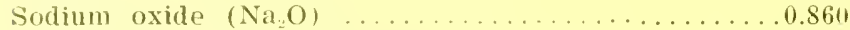

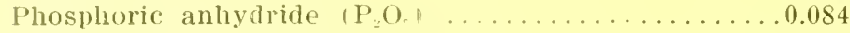

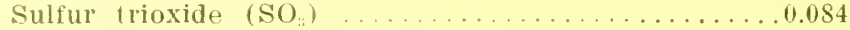

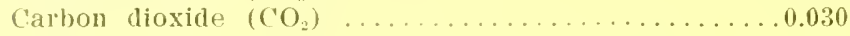

0.062

0.300

0.280

0.450

2.360

0.860

0.079

0.053

0.020

Lime requirement* (CaO) in parts per million.....1,222

Lime requirement $(\mathrm{CaO})$ in pounds per acre foot $\dagger \ldots 4,454$

1,285

4,918

* The Veitch method was used for the determination of lime requirement.

$\div$ Calculated from weight of soil as $3,645,000$ pounds of dry soil per acre foot In the first foot of snil. and $3 . \$ 27.500$ pounds in the second foot.

$$
\text { MIIL NIMIILINI: }
$$

The plats in Series I were sampled both before and after the ten-years period. Soil samples were taken from each plat to a depth of four feet. each foot being kept separate. Six borings were made on each plat. The borings for the same foot were calefully mixed together and a 2-quart sample of each foot of each plat was retained. The soil samples were air-dried and placed in tightly sealed jars.

The plats in Series II were sampled before and after the eight-years period according to the following method: Each llat was divided into three parts-N (north), M (micldle), and $\checkmark$ (south). Each one of these sections was sampled as ontlined for the plats in Series I.

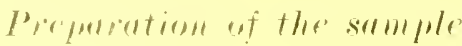

The air-clried soil was brought to a uniform condition by breaking up the soil lumps and carefully mixing. A composite sample was taken and was placed in a 1-millimeter sieve. All particles of the soil that did not pass through the 1-millimeter perforations were discarded. A composite sample was taken 
from the 1-millimeter sample and was passed through a sieve having 100 meshes to an inch. In this case it was necessary to grind the soil in order to pass all of it through the perforations.

In the determinations of carbon the 100-mesh sample was used, while the determinations of nitrogen were made from the 1-millimeter sample. The use of the finer soil in the determination of carbon was based on the uncertainty of obtaining complete combustion with the coarser soil.

The determinations were made in duplicate. All duplicates having a wider discrepancy than 0.02 per cent of carbon and 0.01 per cent of nitrogen were discarded.

\section{Total organic carbon}

The total organic carbon was determined by the Parr Combustion Method, as described in Bulletin 107 (revised) of the United States Bureau of Chemistry, page 234 .

\section{Total nitrogen}

The total nitrogen was determined by the Kjeldahl method. Ten grams of 1-millimeter soil was digested with 30 cubic centimeters of sulfuric acid (specific gravity 1.84) and 0.4 gram of cupric sulfate, in 500-cubic-centimeter Kjeldahl Pyrex flasks at low heat for twenty minutes. Ten grams of potassium sulfate was added and the digestion was continued for three hours. The residue was diluted to 350 cubic centimeters of water and transferred to an S00-cubic-centimeter Kjeldahl flask; from 80 to 90 cubic centimeters of alkali solution was added and the ammonia was distilled into 1-10 N sulfuric acid. The distillate, measuring about 200 cubic centimeters. was titrated with $1-10$ $\mathrm{N}$ sodium hydroxide, two or three drops of methyl red solution being used as an indicator.

SERIES I

soil trentment and cropping systems

The plats in Series I were under experimentation for a period of ten years. from 1910 to 1919 . A statement of the soil 
treatment of each plat, and of the cropping systems. is given in table 1:

'TABle i. Soll Treatanent and Cropping sistems

\begin{tabular}{|c|c|c|c|c|c|}
\hline \multirow{3}{*}{$\begin{array}{l}\text { Plat } \\
7002\end{array}$} & \multicolumn{4}{|c|}{ Sojl treatment } & \multirow{2}{*}{ Cropping system } \\
\hline & \multicolumn{3}{|c|}{ Fertilizer } & Lime & \\
\hline & F:11'm & manure & & None & Rotation without legume \\
\hline 7008 & Farmi & manure & & Burnt lime & Rotation without legume \\
\hline 7003 & Farm & manure & & Nolle & No vegetation \\
\hline 7009 & Farm & manure & & Burnt lime & No vegetation \\
\hline 7005 & Farm & manure & & None & Rotation with legume \\
\hline 7011 & Farm & manure & & Burnt lime & Rotation with legume \\
\hline 7006 & Farm & manure & & None & Oats. grass nine years \\
\hline ¡012 & Farm & manure & & Burnt lime & Oats, grass nine years \\
\hline 7014 & Farm & manure and & $\mathrm{K}_{2} \mathrm{SO}_{4}$ & None & Rutation without \\
\hline 7015 & Farm & mamure and & $\mathrm{K}_{2} \mathrm{SO}_{4}$ & Burnt lime & Rotation without \\
\hline
\end{tabular}

The applications of farm manure were made in 1910, 1914, and 1918. The three applications were each at the rate of 10 tons per acre, and were given to the plats that were never planted as well as to the cropped plats. The applications of potassium sulfate were made annually to plats 7014 and 7015 at the rate of 200 pounds per acre. In 1910 and 1915 burnt lime was applied to plats $7008,7009,7011,7012$, and 7015 , at the rate of 3000 pounds per acre.

The rotation without legume consisted of corn, oats, wheat, and grass two years. In the rotation with legume. clover was grown with grass for two years in the first half of the ten-years peliod, and luring the second half of the ten-years period a legune was grown each year as follows: in 1915. sovbeans with corn; in 1916, peas with oats; in 1917, vetch with wheat; in 1918 and 1919 , clover with grass.

Plats 7003 and 7009 were never planted to any crop, and all vegetation was prevented from growing on them by hoeing. 
When corn was growing on the plats in rotation, the unplanted plats were hoed at the same time and in the same way as were the plats planted to corn: when other crops were growing on the planted plats, the mplanted plats were merely scraped with a hoe.

The mixtures of grasses used consisted of timothy, Kentucky blue grass. and redtop.

$$
\text { liesults }
$$

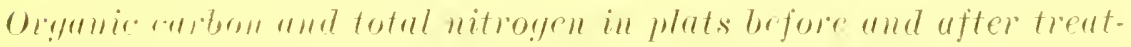
ment

The results recorded in tables 2 and 3 represent the arerages of duplicate determinations. The percentages of carbon and nitrogen before and after treatment are given, as well as the differences and the percentage of increase or decrease for the tenyears period. The total amounts of carbon and nitrogen added to the plats in manure, have been subtracted from the amounts of carbon and nitrogen determined on analysis after treatment.

The data show that in the first foot, in every case but one, the limed plats contained more organic carbon than did the unlimed plats. This is very significant in the plats kept in grass. Plat 7012. kept in grass and limed, shows an increase of 20.5 per cent of organic carbon in comparison to an increase of 14.5 per cent in plat 7006 , which had the same treatment and cropping except that it was not limed. Plat 7002 , cropped in rotation but not limed. shows a decrease of 24.5 per cent of organic carbon in comparison to a loss of 3.1 per cent in plat 7008 . which had received lime. This difference is not attributed entirely to the lime. Plat 7002 was exposed to greater erosion and more complete drainage than was plat 7008 . All plats in rotation show a decrease in organic carbon in the first foot, while there is a marked gain in organic carbon in the first foot in the plats kept permanently in grass.

The use of legumes in rotation did not materially affect the organic carbon content.

Plat 7009. which was kept bare, lost a marked percentage of organic carbon in the first foot.

The percentages of organic carbon in the second foot are 


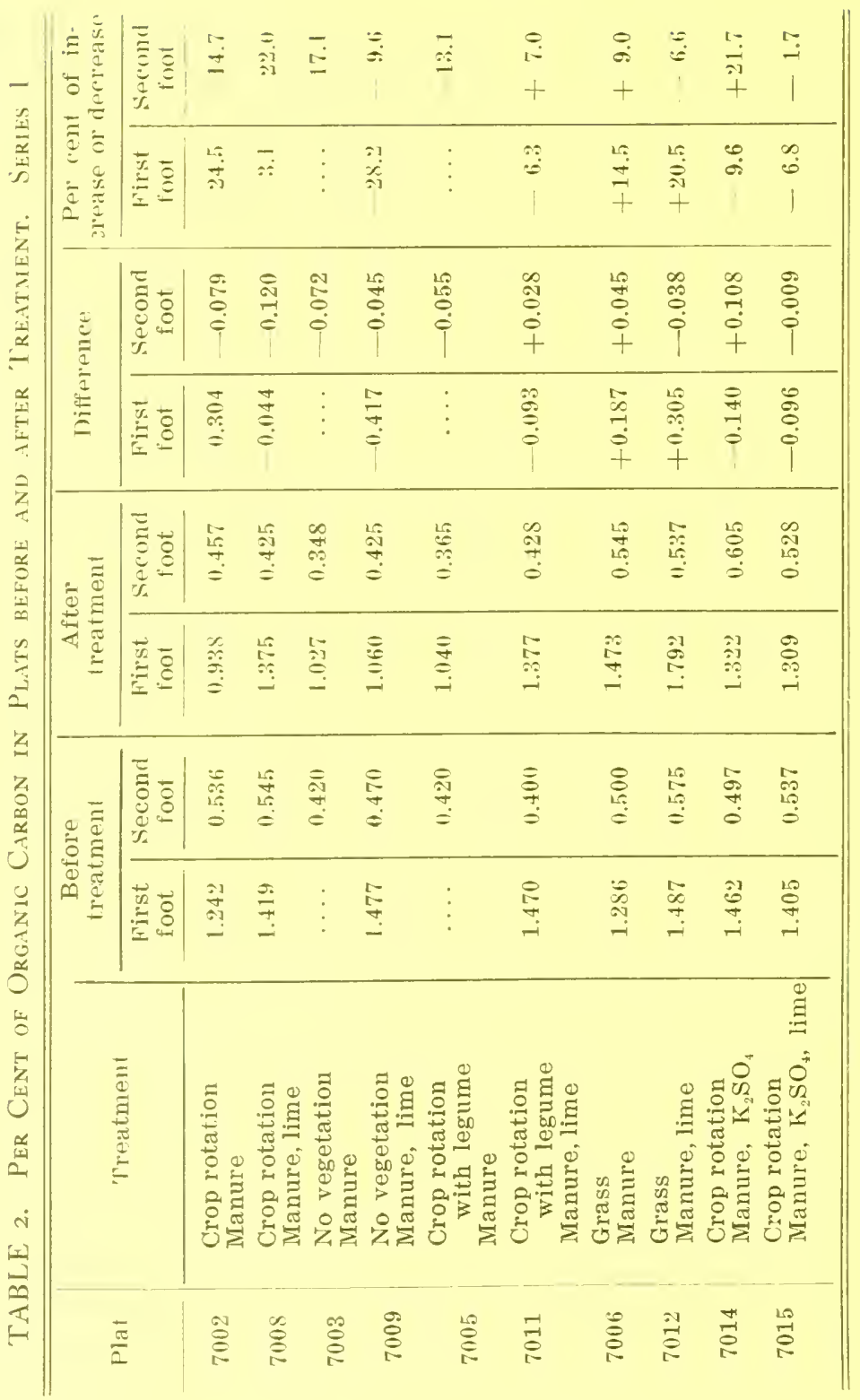


sone Relations of Organid Matter in SoIls

\begin{tabular}{|c|c|c|c|c|c|c|c|c|c|c|c|}
\hline $\begin{array}{l}\Xi \\
\vdots \\
0 \\
0 \\
0\end{array}$ & 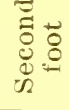 & $\stackrel{\leftrightarrow}{\stackrel{3}{i}}$ & $\stackrel{0}{0}$ & $\begin{array}{l}0 \\
0 \\
81\end{array}$ & $\frac{\pi}{i}$ & $\begin{array}{l}-1 \\
\infty \\
+ \\
+\end{array}$ & $\begin{array}{l}0 \\
0 \\
+\end{array}$ & $\stackrel{5}{9}$ & $\begin{array}{l}\dot{0} \\
1\end{array}$ & $\begin{array}{l}\text { Lo } \\
\infty \\
+ \\
+\end{array}$ & $\begin{array}{l}\breve{-} \\
+\end{array}$ \\
\hline $\begin{array}{cc}0 & 0 \\
0 & 0 \\
1 & 0 \\
0 & 0 \\
0 & 0 \\
0 & 0\end{array}$ & $\stackrel{+}{=}$ & 苚 & $\infty$ & $\vdots$ & $\because$ & $\vdots$ & $\bar{T}$ & $\begin{array}{l}\because \\
+\end{array}$ & $\begin{array}{l}? 1 \\
+1 \\
+\end{array}$ & $\stackrel{\infty}{1}$ & $\stackrel{9}{i j}$ \\
\hline 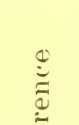 & 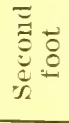 & 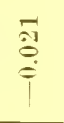 & $\begin{array}{l}=1 \\
9 \\
0 \\
1\end{array}$ & $\hat{\bar{\theta}}$ & $\begin{array}{l}\frac{1}{2} \\
\vdots \\
\overline{1}\end{array}$ & $\begin{array}{l}5 \\
\stackrel{5}{3} \\
\dot{5} \\
+ \\
+\end{array}$ & $\begin{array}{l}\overline{1} \\
= \\
\bar{\vdots} \\
+\end{array}$ & $\begin{array}{l}\vdots 0 \\
\vdots \\
= \\
=\end{array}$ & $\stackrel{5}{=}$ & $\begin{array}{l}3 \\
\vdots \\
0 \\
+\end{array}$ & $\begin{array}{l}\stackrel{g}{0} \\
\dot{+} \\
+\end{array}$ \\
\hline$\stackrel{ \pm}{\Xi}$ & $\begin{array}{l}\overrightarrow{2} \\
\stackrel{2}{0} \\
\stackrel{0}{0}\end{array}$ & $\begin{array}{l}\overrightarrow{7} \\
0 \\
0\end{array}$ & $\stackrel{\vec{b}}{\dot{i}}$ & $\vdots$ & $\begin{array}{l}\infty \\
\vdots \\
\vdots\end{array}$ & : & $\stackrel{\bar{\equiv}}{=}$ & $\begin{array}{l}\stackrel{\grave{3}}{0} \\
\dot{+}\end{array}$ & $\begin{array}{l}\stackrel{\theta}{0} \\
\stackrel{0}{0} \\
+\end{array}$ & $\stackrel{0}{0}$ & $\frac{5}{0}$ \\
\hline$\stackrel{\vec{\Xi}}{\overrightarrow{0}}$ & 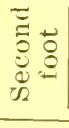 & $\begin{array}{l}\stackrel{0}{10} \\
\stackrel{0}{0} \\
0\end{array}$ & $\frac{\pi}{0}$ & $\stackrel{5}{\stackrel{5}{6}}$ & $\begin{array}{l}\text { 㝬 } \\
= \\
=\end{array}$ & $\begin{array}{l}\stackrel{\vec{D}}{0} \\
=\end{array}$ & $\begin{array}{l}= \\
= \\
=\end{array}$ & 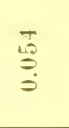 & $\begin{array}{l}\frac{1}{6} \\
\stackrel{0}{0}\end{array}$ & $\begin{array}{l}0 \\
\stackrel{1}{0} \\
0\end{array}$ & $\stackrel{\mathscr{B}}{\stackrel{B}{=}}$ \\
\hline$\Xi$ & 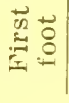 & $\begin{array}{l}\stackrel{H}{\infty} \\
\stackrel{8}{0}\end{array}$ & $\begin{array}{l}\stackrel{\infty}{\leftrightarrows} \\
=\end{array}$ & $\begin{array}{l}\stackrel{\Xi}{O} \\
\stackrel{g}{=}\end{array}$ & $\begin{array}{l}\underline{I} \\
= \\
=\end{array}$ & $\stackrel{12}{=}$ & $\begin{array}{l}3 \\
= \\
=\end{array}$ & 管 & $\begin{array}{l}50 \\
\frac{6}{0} \\
0\end{array}$ & $\begin{array}{l}\stackrel{20}{S} \\
\stackrel{-}{=}\end{array}$ & $\begin{array}{l}\frac{10}{9} \\
\stackrel{7}{\circ} \\
0\end{array}$ \\
\hline$\stackrel{ٌ}{\Xi} \stackrel{\Xi}{\Xi}$ & 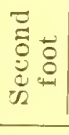 & $\begin{array}{l}1= \\
0 \\
0\end{array}$ & $\begin{array}{l}19 \\
\stackrel{8}{8} \\
0\end{array}$ & $\begin{array}{l}气 \\
气 \\
=\end{array}$ & 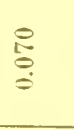 & $\begin{array}{l}\frac{\pi}{3} \\
\vdots \\
0\end{array}$ & $\begin{array}{l}\frac{3}{0} \\
= \\
=\end{array}$ & 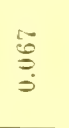 & $\stackrel{\Xi}{0}$ & 量 & $\begin{array}{l}\vec{\infty} \\
\stackrel{\infty}{0}\end{array}$ \\
\hline$\oplus \stackrel{\pi}{\varrho}$ & 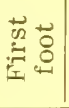 & $\begin{array}{l}\hat{0} \\
\stackrel{0}{0} \\
0\end{array}$ & $\begin{array}{l}\stackrel{\infty}{0} \\
\stackrel{-1}{0} \\
0\end{array}$ & $\vdots$ & $\begin{array}{l}10 \\
\stackrel{10}{-1} \\
\stackrel{-1}{=}\end{array}$ & $\vdots$ & $\begin{array}{l}\stackrel{5}{+} \\
\stackrel{+}{\leftrightarrows} \\
=\end{array}$ & $\begin{array}{l}\overrightarrow{3} \\
\overrightarrow{3} \\
\overrightarrow{0}\end{array}$ & $\begin{array}{l}\overrightarrow{B 0} \\
\stackrel{0}{0}\end{array}$ & 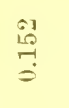 & $\stackrel{\stackrel{v}{J}}{\leftrightarrows}$ \\
\hline 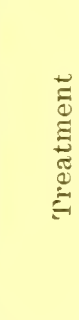 & & 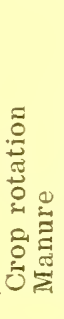 & 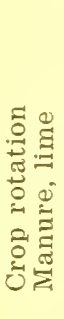 & 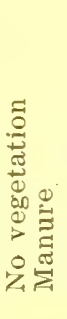 & 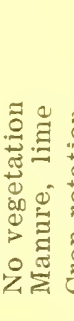 & 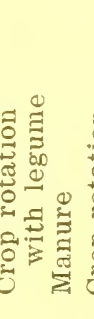 & 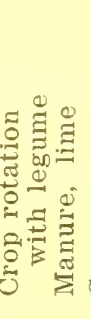 & 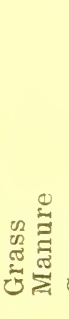 & 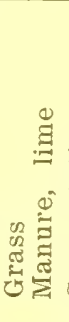 & 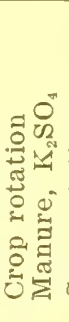 & 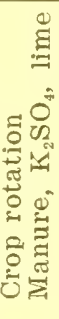 \\
\hline$\frac{\pi}{2}$ & & $\stackrel{\vartheta}{8}$ & $\stackrel{\infty}{8}$ & $\stackrel{\infty}{8}$ & $\underset{8}{8}$ & $\stackrel{10}{8}$ & 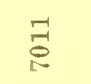 & $\stackrel{\circ}{8}$ & 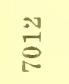 & $\stackrel{\vec{S}}{\sigma}$ & $\frac{10}{6}$ \\
\hline
\end{tabular}


less consistent than those in the first foot. This inconsistency may be accomnted for by lack of soil miformity.

The limed plats not only contained more organic carbon, but also gave higher vields, than the unlimed plats. The yields are expressed in graph form in figure 1 (page 17).

With one exception thele was a greater percentage of nitrogen in the limed plats than in the unlimed plats. The plats in rotation all showed a loss of nitrogen in the first foot for the ten-year's period, while the plats in grass increased in nitrogen. Plat 7009, which was kept bare. lost a marked percentage of nitrogen in the first foot. Plat 7011 . on which the rotation included legumes, lost a smaller percentage of nitrogen in the first foot than did the plats in rotation without legumes.

These results are consistent with the results obtained on the lysimeter tanks (Lyon and Bizzell. 1918). The soil in the lysimetel tanks was obtained from the plats used in these experiments. It was found that the nitrogen in the drainage water from the lysimeter tanks was less where the tank soils had been kept in grass. than in a rotation. It was shown also that the tank soils kept bare lost mole nitrogen than the cropped tank soils.

Putio of carbon to nitionen in phuts Thefore and ufter treatment

The ratios of carbon to nitrogen in plats before and after treatment are given in table 1 . The data show the close relation between these two elements in the soils studied. The ratio was wider in the first foot of soil than in the second foot. The various treatments did not cause any constant change in the carbonnitlogen ratio. The effect, if any. was too inconsistent to be considered significant.

The results compare farorably with those obtained by Hess (1901). He found that the ratio of carbon to nitrogen was not materially affected by the treatment applied. Dyer (1902) also reported that the carbon and nitrogen contents of the upper stratum of the soil were higher than those of the lower stratum. and that the ratio of carbon to nitrogen was wider in the upper stratum. Alway and McDole (1916) likewise found that the ratio of carbon to nitrogen was lower in the second foot than in the surface foot. 


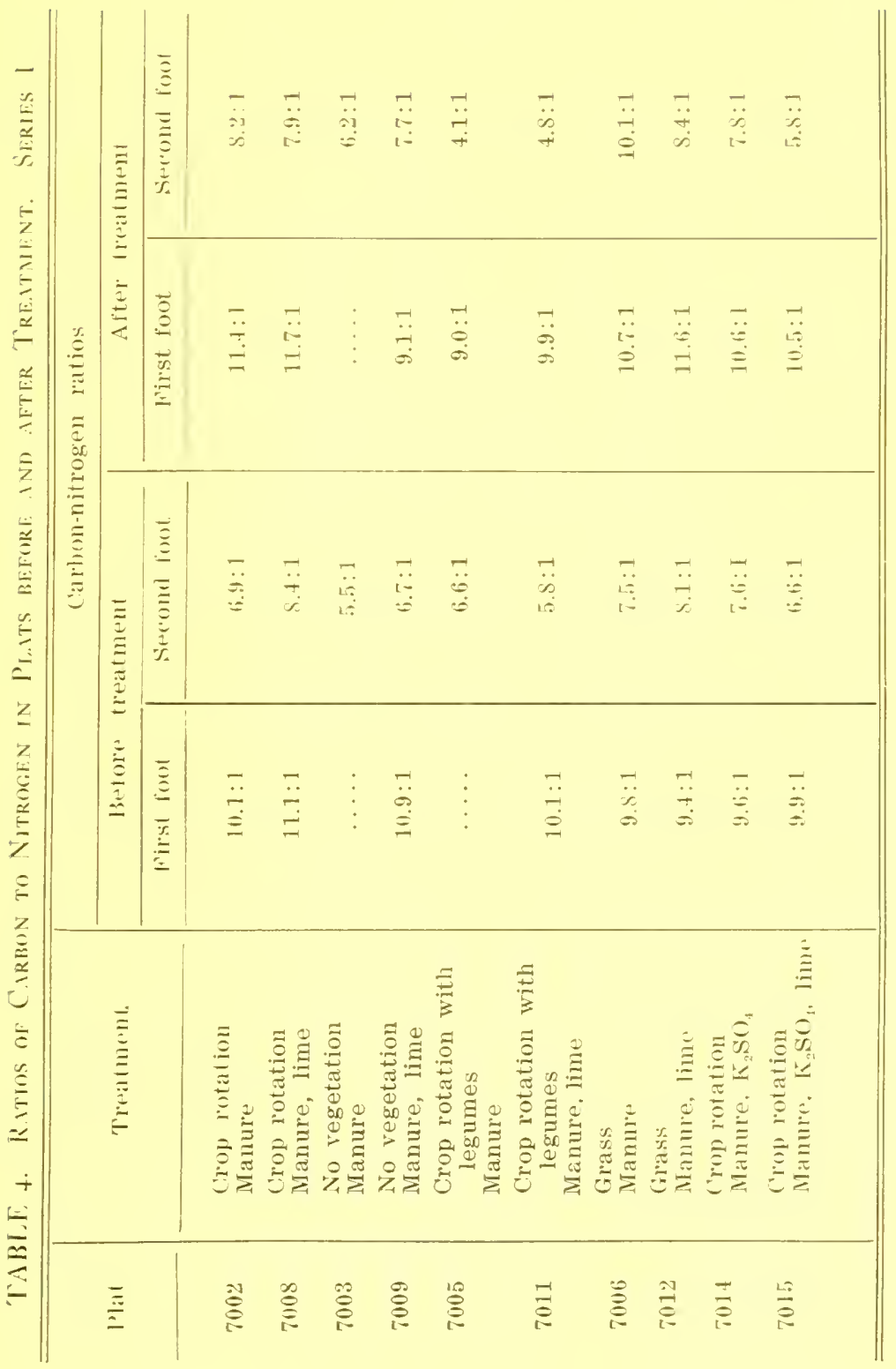


Remocul of nitronen from the soil in crops grown on the plats in series 1

The amounts of nitrogen removed in the crops were estimated and are recorded in table 5. The nitrogen is expressed in pounds per acre for the ten-years period.

Table 5. Anount of Nitrogen in Crops. Series I

\begin{tabular}{|c|c|c|c|c|}
\hline Plat & Crop & Fertilizer & $\begin{array}{l}\text { Burnt } \\
\text { lime } \\
\text { (pounds) }\end{array}$ & $\begin{array}{l}\text { Nitrogen in crops } \\
\text { (pounds per acre. } \\
\text { total for ten years) }\end{array}$ \\
\hline 7002 & $\begin{array}{c}\text { Rotation with- } \\
\text { ont legume }\end{array}$ & Farm manure & 0 & 684 \\
\hline 7008 & $\begin{array}{l}\text { Rotation with- } \\
\text { out legume }\end{array}$ & Farm manure & 9.000 & 798 \\
\hline 7005 & $\begin{array}{l}\text { Rotation with } \\
\text { legume }\end{array}$ & Farm manure & 0 & 817 \\
\hline 7011 & $\begin{array}{l}\text { Rotation with } \\
\text { legume }\end{array}$ & Farm manure & 9.000 & 948 \\
\hline 7006 & Grass & Farm manure & 0 & 325 \\
\hline 7012 & Grass & Farm manure & 9.000 & 354 \\
\hline 7014 & $\begin{array}{c}\text { Rotation with- } \\
\text { out legume }\end{array}$ & Farm manure and $\mathrm{K}_{2} \mathrm{SO}_{4}$ & (1) & $\$ 44$ \\
\hline 7015 & $\begin{array}{l}\text { Rotation with- } \\
\text { out legume }\end{array}$ & Farm manure and $\mathrm{K}_{2} \mathrm{SO}_{4}$ & 9,000 & 868 \\
\hline
\end{tabular}

It appears that the nitrogen varies with different crops. The greatest removal of nitrogen was in the crops in rotation with legumes. The hay crops removed less than half the amounts of nitrogen estimated in the crops in rotation with legumes. These results are of extreme importance in considering the total nitrogen in the soils of these plats recorded in table 3, in which, as already stated, it is shown that the plats kept in grass increased in nitrogen in the first foot, while the plats in rotation with legumes and those in rotation without legumes decreased in nitrogen. The fact that less nitrogen was removed from the grass plats may aid in some degree in explaining these differences in percentages of nitrogen. 
Total yields of crops on plats in Series I

The total yields of crops in Series I are represented in figure 1 .

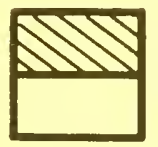

WITHOUT LIME

WITH LIME

Field

weight

(lbs.)

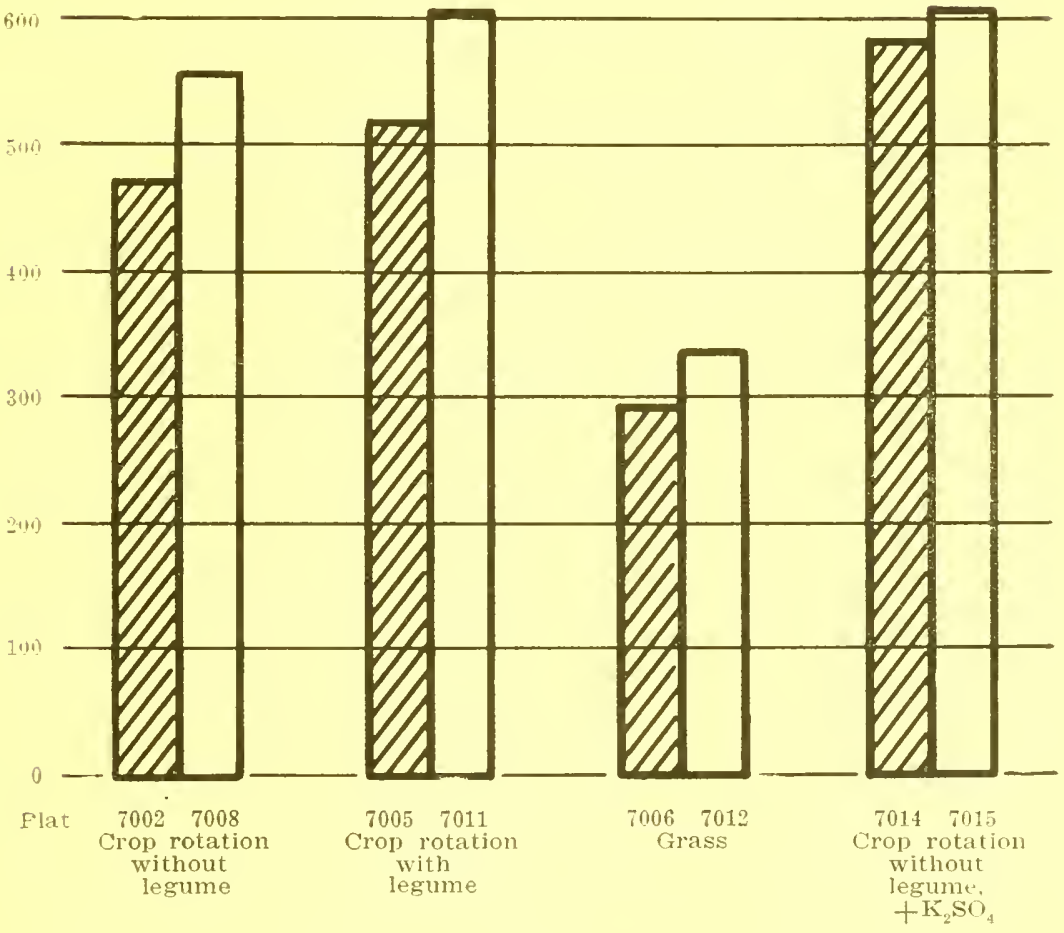

FIG. I. TOTAL PLAT YIELDS FOR TEN-YEARS PERIODS, SERIES I

In every case there was an increase in crop yield on the limed plats over that on the unlimed plats. It seems logical to 
assume that an increase in yield is associated with an increase in roots and residual organic matter, which may explain why the organic carbon and the nitrogen were generally higher in the limed plats than in the unlimed plats.

The total yields were less on the plats kept permanently in grass than on the plats in rotation with legumes or on those in rotation without legumes. It has ahready been pointed out, in tables : and 3, that the plats in rotation lost more organic carbon and nitrogen in the first foot than did the grass plats.

\section{SERIES II}

In order to obtain further information on the effect of treatment and cropping on the organic carbon and the nitrogen in soils, the plats in Series II, located adjacent to plats in Series I, were analyzed. These plats, as already stated, received approximately the same treatment as the plats in Series I, the only marked differences being that the plats of Series II were started one year later than the plats of Series $I$, and that they receired only two applications of manure.

Only the first foot was analyzed, due to the failure of the second foot in Series I to show any consistent results of experimental value.

The results obtained are recorded in tables 6,7 , and $s$. These tables are not discussed separately, due to their close correlation with the results of Series I.

The points emphasized in discussing the results of Series I may well be applied to Series II. However, the results in Series II are much more striking. The limed plats, as was found in Series I, show in general a higher percentage of organic carbon and of nitrogen than do the unlimed plats. The limed plats also gave higher yields than did the unlimed plats. There was a decrease in organic carbon and in nitrogen in the plats cropped under the rotation without legumes, with one exception.

The most interesting phase of these results is that the plats in rotation with legumes showed an increase in nitrogen. The percentages are very significant. Plats 7205 and 7211 , in rotation with legumes, increased 4.2 and 6.7 per cent, respectively. in comparison to plats 7202 and 7208 , in rotation without legumes, which decreased in nitrogen 12.2 and 7.1 per cent, respectively. 


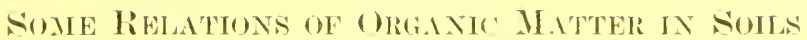

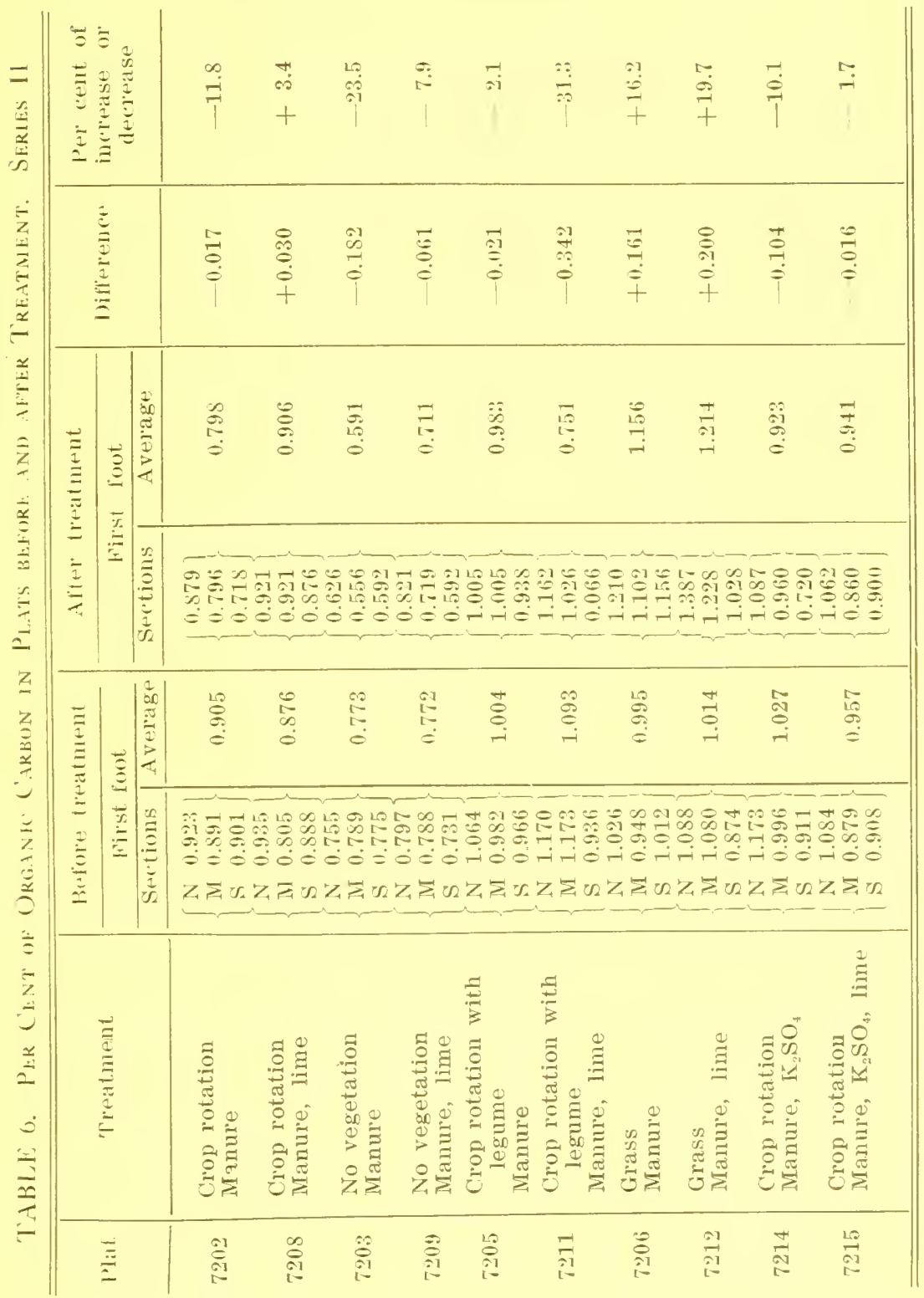




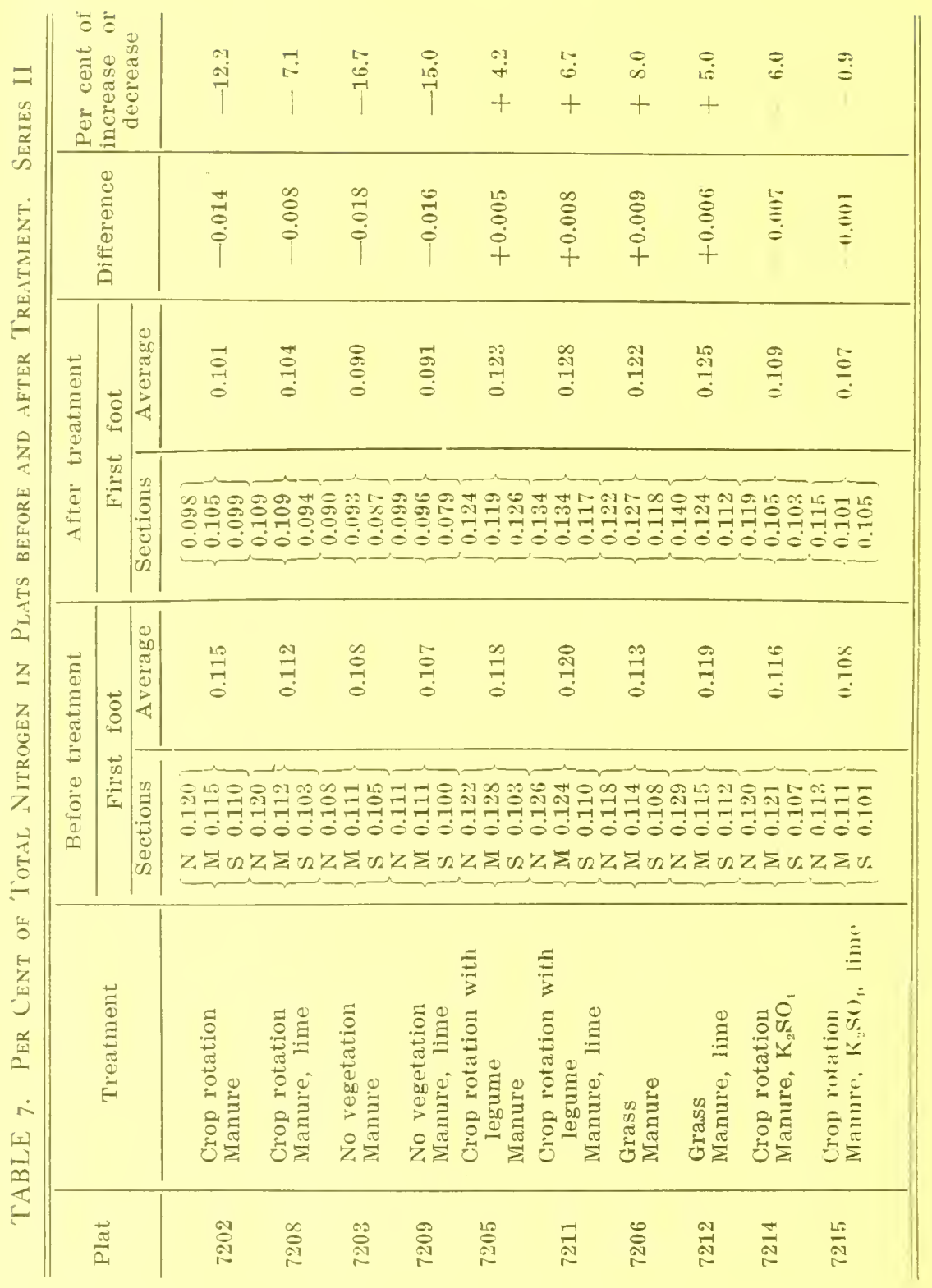


Table 8. Ratios of Carbon to Nitrogen in Plats before and after Treatient. Series II, First Foot of Soll

\begin{tabular}{|c|c|c|c|}
\hline \multirow[b]{2}{*}{ Plat } & \multirow[b]{2}{*}{ Treatment } & \multicolumn{2}{|c|}{ Carbon-nitrogen ratios } \\
\hline & & Before treatment & After treatment \\
\hline 7202 & $\begin{array}{l}\text { Crop rotation } \\
\text { Manure }\end{array}$ & $7.9: 1$ & $7.9: 1$ \\
\hline 72115 & $\begin{array}{l}\text { Crop rotation } \\
\text { Manure, lime }\end{array}$ & $7.8: 1$ & $8.7: 1$ \\
\hline $720 ?$ & $\begin{array}{l}\text { No vegetation } \\
\text { Manure }\end{array}$ & $7.2: 1$ & $6.6: 1$ \\
\hline 7209 & $\begin{array}{l}\text { No vegetation } \\
\text { Manure, lime }\end{array}$ & $7.2: 1$ & $7.9: 1$ \\
\hline 7205 & $\begin{array}{l}\text { Crop rotation with } \\
\text { legmme } \\
\text { Ianmre }\end{array}$ & $8.5: 1$ & $7.9: 1$ \\
\hline$\because 211$ & $\begin{array}{l}\text { Crop rotation with } \\
\text { legume } \\
\text { Manure, lime }\end{array}$ & $9.1: 1$ & $9.5: 1$ \\
\hline 72060 & $\begin{array}{l}\text { Grass } \\
\text { Manure }\end{array}$ & $8.8: 1$ & $9.5: 1$ \\
\hline 7212 & $\begin{array}{l}\text { Grass } \\
\text { Manure, lime }\end{array}$ & $8.2: 1$ & $9.7: 1$ \\
\hline 7214 & $\begin{array}{l}\text { Crop rotatiou } \\
\text { Manure, } \mathrm{K}_{2} \mathrm{SO}_{4}\end{array}$ & $8.9: 1$ & $9.5: 1$ \\
\hline 7215 & $\begin{array}{l}\text { Crop rotation } \\
\text { Manure. } \mathrm{K}_{2} \mathrm{SO}_{4} \text {, lime }\end{array}$ & $\$ .9: 1$ & \$.8:1 \\
\hline
\end{tabular}

The plats in grass showed a decided increase in organic carbon and in nitrogen.

The carbon-nitrogen latios were lower than those in Series I.

Remocal of nitrogen from the soil in crops groun on the pluts in sifries II

The amounts of nitrogen removed in the crops grown on the plats of Series II were estimated and are recorded in table 9. The nitrogen is expressed in pounds per acre.

The results compare favorably with those obtained in the study of the plats in Series I. In considering the nitrogen in the soils of the plats in rotation with legumes, as recorded in 
TABLE 9. Amount of Nitrogen in Crops. Series II

\begin{tabular}{|c|c|c|c|c|c|}
\hline Plat & Crop & & Fertilizer & $\begin{array}{c}\text { Burnt } \\
\text { lime } \\
\text { (pounds) }\end{array}$ & $\begin{array}{l}\text { Nitrogen in crops } \\
\text { (pomnds per acre, } \\
\text { total for ejght years) }\end{array}$ \\
\hline $7: 02$ & $\begin{array}{c}\text { Rotation with- } \\
\text { out legume }\end{array}$ & Farm & manure & 0 & 55.5 \\
\hline $720 s$ & $\begin{array}{l}\text { Rotation with- } \\
\text { out legume }\end{array}$ & Farm & manure & 9.0000 & 714 \\
\hline 7205 & $\begin{array}{l}\text { Rotation with } \\
\text { legume }\end{array}$ & Farm & manure & 0 & 690 \\
\hline 7211 & $\begin{array}{l}\text { Rotation with } \\
\text { legume }\end{array}$ & Farm & manure & 9.0000 & $\$ 92$ \\
\hline 7206 & Grass & Farm & manure & 0 & 312 \\
\hline 7212 & Grass & Farm & manure & 9,0010 & 397 \\
\hline 7214 & $\begin{array}{c}\text { Rotation with- } \\
\text { out logume }\end{array}$ & Farm & manure and $\mathrm{K}_{2} \mathrm{SO}_{4}$ & 0 & 652 \\
\hline 7215 & $\begin{array}{c}\text { Rotation with- } \\
\text { out legume }\end{array}$ & Farm & manure and $\mathrm{K}_{2} \mathrm{SO}_{4}$ & 9,000 & 703 \\
\hline
\end{tabular}

table 7 , and that removed by the crops, the advantage from the growing of legumes is fully substantiated. The crops in rotation with legumes removed more nitrogen than did the crops in rotation without legnumes. In this comnection it is important to note also in table 7 that the plats in rotation with legumes contained more nitrogen than did the plats in rotation without legumes. While the plats kept in grass contained more nitrogen than dic the plats in rotation, there is a marked difference in the amount of nitrogen removed by the hay crop as compared with the crops in rotation with legumes. The results show that the rotation with legumes used in these experiments supplied more nitrogen than did the rotation without legumes or the grass.

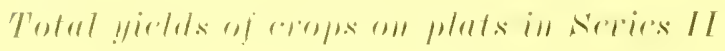

The total yields of crops in Series $1 \mathrm{I}$ are represented in figure 2. The limed plats show a greater yield than the mulimed plats. This was true also of the plats in Series I. The total vields, 
however. of both the limed and the unlimed plats in Series II are less than those in Series I. It may be pointed out here that the plats in Series II contained less organic carbon and nitrogen than the plats in Series I. This may indicate that there is some relation between organic carbon and nitrogen, and yields of crops.

Field

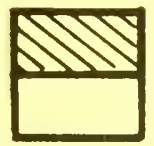

WITHOUT LIME

WITA $\angle I M E$

weight

(lbs.)

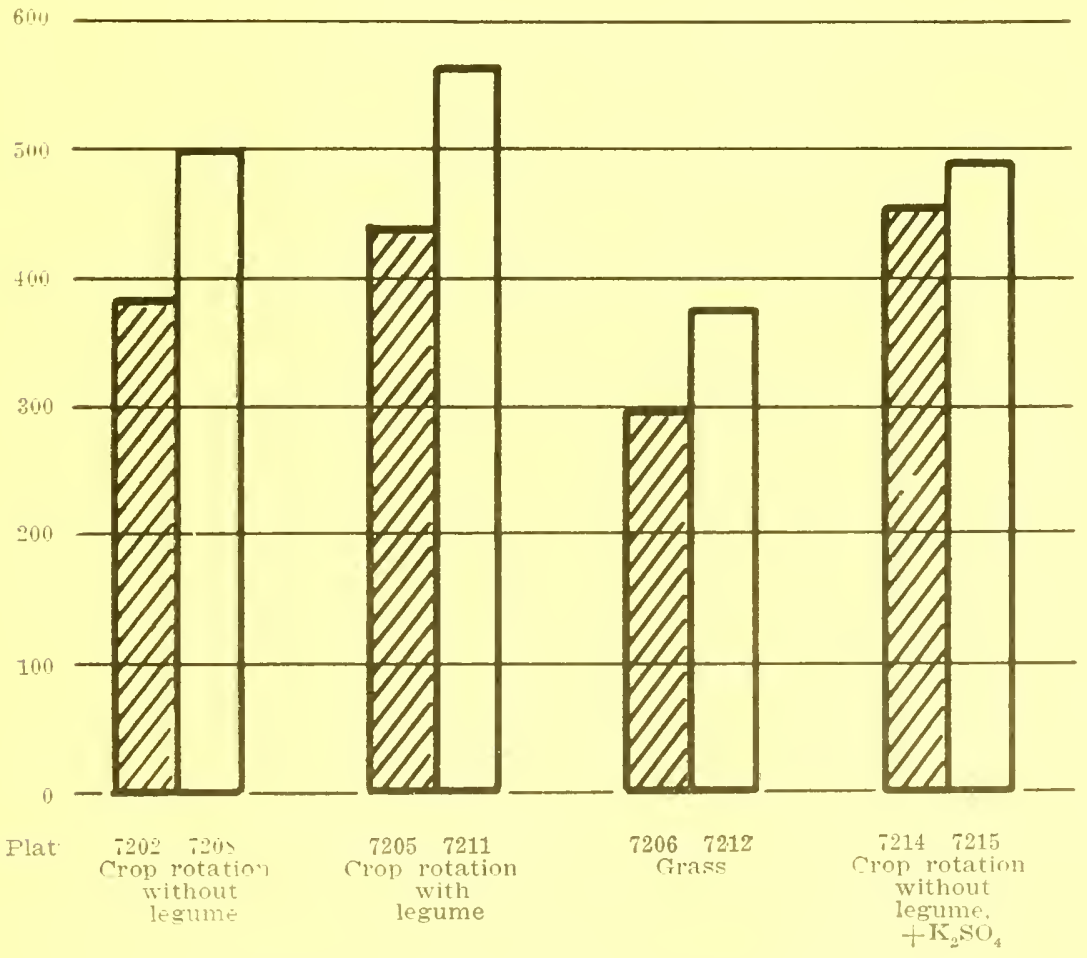

FIG 2. TOT.IL PLAT YIELDS FOR EIGHTMYEARS PERIODS, SERIES II 
The most important result shown in figures 1 and 2 , as related to the present investigation, is the increase in yields of crops on the limed plats over those on the unlimed plats.

\section{SUMMALI}

A study of the effect of various treatments and cropping systems on the organic-carbon and the nitrogen in soil is reported in this paper. The soil is classified as a Dunkirk clay loam. The plats were each $1 / 100$ of an acre in size and were arranged in two series. The treatments included manure, potassium sulfate, and lime. The cropping consisted of a rotation without legumes, a rotation with legumes, and grass permanently. The experiment was conducted for periods of eight and ten year's, respectively.

The plats were sampled for the first- and second-foot strata before and after treatment.

The organic carbon and the nitrogen were determined.

The results of the two series compared favorably.

In general the limed plats in both series contained more organic carbon and nitrogen than did the unlimed plats.

There was a decrease in organic carbon and in nitrogen at the end of the period of experimentation on the plats in rotation without legumes.

The plats kept in grass showed an increase in organic carbon and in nitrogen.

The plats in rotation with legumes contained more nitrogen than did the plats in rotation without legumes. The plats in rotation with legumes in Series II showed a marked increase in nitrogen. The increase was greater in the limed plats than in the unlimed plats. This fact seems to indicate that the legumes had some influence on the nitrogen content of the soil studied.

The organic carbon and the nitrogen were lower in the plats of Series II than in the plats of Series I.

The limed plats produced higher vields of crops than did the unlimed plats.

The plats in Series I gave higher yields of crops than did the plats in Series II.

The results suggest that there is some relation between organic carbon and nitrogen, and yields of crops. 
The crops in rotation with legumes removed more nitrogen from the soil than did the crops in rotation without legumes.

The plats kept in grass lost less nitrogen in the crops than did the plats in rotation with legumes.

There is a close relation between the organic carbon and the nitrogen. The ratio is wider in the first foot of soil than in the second foot.

\section{REFERENCES CITED}

Alway, Frederick J.. Axi, MaDole, Gur R. The loess soils of the Nebraska portion of the transition region: I. Hygroscopicity, nitrogen. and organic carbon. Soil sci. 1 :197-238. 1916.

AlwaY, F. J., and Trumbull, R. s. A contribution to our knowledge of the nitrogen problem under dry farming. . Tomrn. indus. and ens. chem. : :135-138, 1910.

Bear, Finman E. Effect of quicklime on olganic mattel in soils. Amer. Soc. Agron. Journ. S:111-113. 1916.

Bizzel, .T. A. ANm LToN, T. L. The effect of certain factors on the carbon-dioxid" content of soil air. Amer. Snc. Agron. Journ. 10:97-112. 1918.

Brader. C. E. The soils of Gregon. Oregon Agr. Exp. Sta. Bul. $112: 1-48.1912$.

Breazeale, J. R. Folmation of "black alkali" (sodimm carbonate) in calcareous soils. Tourn. agr. res. 10:541-590. 1917.

Christie, A. W., and Martin. .T. C. The chemical effects of CaO and $\mathrm{CaCO}_{3}$ on the soil. Part II. The effect on watel-soluble nutrients in soils. Soil sci. ;:383-392, 1918 .

Clausen, H. [German title.] Can calcareous fertilizers be held responsible for a deficiency of nitrogen in soils? Illus. landw. Ztg. 26:674-675. rited in Exp. sta. rec. 18:622-623. 1907. i 1906.

Dyer, Bernaro. Results of investigations on the Rothamsted soils. U. S. Cffice Exp. Sta. Bul. 106:1-1s0. Reference on p. 29.) 1902 .

Gardner, Frank D. The use of lime on land. H'enmsylvania Agr. Exp. Sta. Bul. $131: 167-204.1914$. 
Hartwell. B. L.. ANI Kelgoga, J. W. On the eftect of liming upon celtain constituents of a soil. Rhole Iskand Agr. Exp. Sta. Rept. 1905: 242-252. 1906.

Hess, Exos H. Eifect of varions systems of fertilizing upon the loumus of the soil. Penmsylvania state coll. Inn. rept. 1599. 190()$^{2}: 183-202.1901$.

Jexsex, ('Harles 1 . Humus in mulched basins, relition of hmmms content to oramge production, and effect of mmlohes on

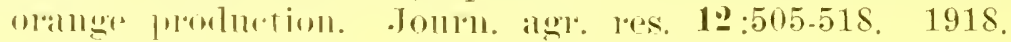

Kossorith, P.. Anu 'lretukoy, I. [Russian title.] On the intlu-

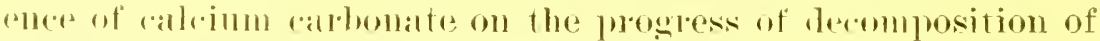
organic matter. Zhur. Opuitu. Agron. 3:450-484. prited in Ex]. sta. res, 14:427. 1903.) 1902 .

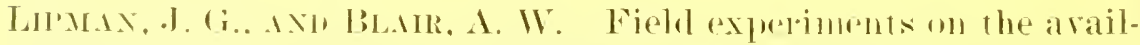
aloility of nitrogenous fertilizers. Xew Jersey der. Exp. Sta. Bul. $260: 1-33.1913$.

The lime factor in pernament soil imporrement.

lootations willomt legumes. Soil sci. 9: \$3-90. 1920 a.

'llar lime lactor in permanent soil imperovement. II. Rotations with legumes. Soil sei. 9:91-114, 1920 h.

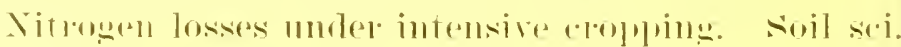
$12: 1-19 . \quad 1921$.

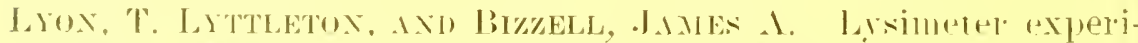

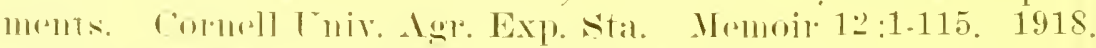

Matrine. W. H. liesmlts of thirty years of liming. Tennsylvamia state roll. Amm. rept. 1911-i22:64-75. 1913.

Mookrs. C. A., Hampton, H. П., Ani Huxtel, W. К. Fertility experintelts in a rotation of cowpeas ame whatt latet III.

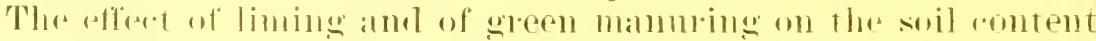

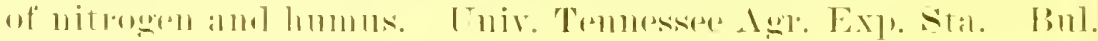
$96: 25-43 . \quad 1912$.

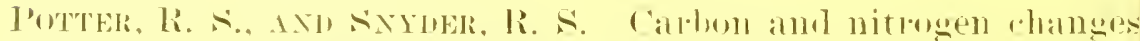
in the soil varionsly treated: soil treated with lime. almmo. nimm sulfate. and solium nitrate. Soil sei. $1: 76-94.1916$.

Decomprosition of green and stable 111 anmes in soil .Jo1111. ag1. res. 11:677-698. 1917. 
Suchtrlen, F'. H. H. Tan. Ueber die Messung del Lebenstaetigkeit dor aerobiotischen Bakterien im Boden durch die Kohlensaeureproduktion. ('entbl. Bakt. $2: 28: 45.89 .1910$.

swaxon, C. O. The loss of nitrogen and organic matter in cultivaterl Kansas soils and the effect of this loss on the crop-prolucing power of the soil. Tourn. indus. and eng. chem. $7: 529$. 532. 1915.

SWANSON, C. O., AnI LATSHAT, W. L. Effect of alfalfa on the fertility elements of the soil in comparison with grain crops. Soil sci. $8: 1-39 . \quad 1919$.

Wheeler, H. .J., Sargent, C. L., and Hartwell, B. L. The anomut of humus in soils and the percentage of nitrogen in the humms, as affected hy applirations of air-slacked lime and cerlaiu other substances. Rhorle Tsham Agl: Fxp. Stal. Anu. rept. 12:15215!. 1899.

Memolr 57. A study, by the Crop survey Method, of liuctors Infuencing the lield of potutnes, the rourtb preceding number in this series of publications, was mailed on September $27,1922$. 

LIBRARY OF CONGRESS

L IBRARY OF CONGR ES 